Драган Б. Бошковић*

Универзитет у Крагујевцу

Филолошко-уметнички факултет

Одсек за филологију

Катедра за српску књижевност

https://doi.org/10.18485/ai_petrovic_goran.2020.ch1

821.163.41.09 Петровић Г.

\title{
МАЛА, ЈЕДНОДНЕВНА, НА ТЕМПЕРАТУРИ ОД 37 СТЕПЕНИ, МЕДИТАЦИЈА ДРАГАНА БОШКОВИЋА О ПОЕТИЦИ ГОРАНА ПЕТРОВИЋА
}

$\mathrm{y}$ тексту је требало да буде речи о белезима/жиговима/ траговима људскости у делу Горана Петровића, и о његовој аутопоетичкој одбрани књижевности. У њему је, међутим, проговорено о поетици Горана Петровића, која се мисли као књижевнокултуролошка седиментација, а заједно са Петровићем и Фукоом као археолошка поетика. А поетичко-археолошки знакови Горана Петровића препознати су као трансисторијски трагови хуманитета. Зато се у тексту осећа дух вере у литературу, елементарно хумане вере и наде да, док има писаца и књижевности, ипак није све отишло бестрага.

Кључне речи: Горан Петровић, књижевност, поетика, археолошка поетика, (књижевнокултурна) седиментација, реч-слика, хуманитет

Пре неких сада већ петнаестак година, имао сам прилику да слушам Горана Петровића на његовој промоцији у Бијељини. Мислим да сам добро запамтио један пасаж

* boskovicbdragan@gmail.com 
његовог излагања, у којем је своју поетику представио посредством фигуре седиментације, у смислу геолошке, али и археолошке седиментације, књижевне и лингвистичке, суштински: културолошке седиментације. Ако ме памћење не вара, у шта увек сумњам, Горан је рекао да поетички облик његове прозе јесте дијахронијска седиментација хуманитета као седиментација и поетика и културе и речи, једно дубинско раскривање слоја по слој наслаганих и тако деликатно искристалисаних знакова, које досеже у архајске облике писма, језика, културе. Тако некако је говорио Горан Петровић, и у том моменту спознао сам следеће: поетика Горана Петровића разликује се од поетике једног другог Петровића, Растка. Уколико Растко реч види као „отвор” на, како је сам представио, антрополошком левку, а испод ње, све шири и шири нижу се, феноменолошки, слојеви значења, утисака, менталне пажње, подсвесног и архајског, све дубље, онтолошком бескрају, Горан Петровић, рекао бих, види не тек реч, не знак, већ књижевно-поетички облик језика, културе и књижевности као вертикални књижевнокултуролошки тунел, као трансисторијски цилиндар. Речи за Горана нису, у Растковом смислу, осамостаљене, изловане, „шпијунке” у нешто друго; Горан чак не види осамостаљену реч; за њега је у речи увек друга реч, седимент речи, лексички кристал, семантички атом; за њега је она увек однос (и синхронијски и дијахронијски) према другој речи, оној поред ње или оној (као траг, белег) скривеној у њој, она је, наиме, увек фигура, она је и прича и један вековима, у петрификованим слојевима културе структуриран, а тако динамични ничеански троп: истовремени троп савременог и архајског. Археолошка поетика и нарација Горана Петровића сведочи да се савремена, али и будућа поетика гради у оном закономерном облику поетике којом смо археолошки одређени: 
„Алхемија писања јесте процес мање или више свесног засићења и кристализације, преузимања и комбиновања, експлозија и имплозија... На трагу те метафоре надам се да не претварам више метале у ниже, односно да новостворена једињења имају сврху, да се могу употребити као мелем, као онај танки слој племенитог нечега чиме пресвлачимо болно ништа." (Петровић 2001)

И одједном, тада, у Бјељини, и сада, за радним столом у Београду, испред мене су се отворили толики слојеви бића и значења, раскрио се онај деликатни културолошки поредак толико некомпатибилан са савременошћу, а опет толико савремен, да не кажем свевремен поредак. Ако језик, па и руде, метали, седиментирани слојеви природе и хуманитета постоје по облику поетике, културе, онда нам Горан Петровић својом поетиком открива по ком то облику они постоје: у сваком случају, у форми једне, археолошки и временски, непрекинуте приче. Не може се српски језик, српски роман видети (јер нико роман нити језик никада видео није!), не може се ни препознати у феноменолошко-лингвистичком смислу или у феноменолошко-литерарном смислу: језик и роман се могу видити само по поетичком облику који му писац даје. Исти је случај са физиком, природом, космосом, који не постоје изван културно-поетичке форме.

\section{Растко Петровић је записао}

„Сећам се да сам имао стари један нидерландски албум са енциклопедијским мапама познавања природе, механике и културе. Тамо беше добро литографисаних биљака свију геолошких времена, физичких принципа локомоције и астрономских карата. Ниједно друго дело не би ме задовољило као то." (Петровић 1974а: 114) 
Да је Растко могао да прочита неки роман Горана Петровића, можда би га, са свим енциклопедизованим геолошки седиментираним слојевима језика и културе, он задовољио.

Послушајмо сада и Горана:

„Подрум, као и сваки други, 'скупља' старе ствари и људе. Склони смо да врло лако одбацимо све што нас, између осталог, чини оваквим какви јесмо. Одете на бувљак и видите колико не бринемо о то мало континуитета који имамо, готово је невероватно какве се књиге избацују из библиотека... Нечији животи и успомене сабију се у дветри кутије, онда оне оду на врх неког ормара, па се у једном тренутку нађу у подруму, да би у наредном моменту дошле до контејнера. Следећи корак је бувљак. А свака та кутија има причу..." (Петровић 2011)

Колика је разлика између Растковог „нидерландског албума", да не кажем атласа, и Горанове кутије, разлика између раномодернистичке психолошко-феноменолошко-антрополошке нарације и постмодернистичке културноархеолошке, разлика између фројдизма и фукоизма. Ту недоумицу остављам вама, а мени остаје још макар једно поређење два писца. Ако је жеља Расткова

„чути, као далеки и блиски шум, као брујање, све оно што говоре, што су говорили и што ће говорити људи свих времена и човечанстава; моћи прочитати све оно што су записале људске руке" (Петровић 19746: 473),

Горан Петровић нам је омогућио да то чујемо и то без шума, да видимо без сенке. Ако Растко хоће речи, шум, бруј, Горан хоће валере речи, речи-слике... Зар и архајска мисао, представа, није слика; зар сваки архајски појам није истовремено и слика. Из заборава гледања, Горан 
нас тако снажно буди. И, зато, подвлачим и ово: антрополошка седиментација води нас сликама, у пећинама, на предметима, води нас стању у којем се апстрактна мисао види као праслика, а идеално се, у платоничарском смислу, раскрива у сопственој презентацији. Горанова проза је, дакле, сликовита, она мења мнемоничка и перцептилна очекивања читаоца, она се гледа, она се не чита... (Зар само ова чињеница није довољна да Горан буде издвојен као тако посебан прозаист). Зато је Горанова поетика исувише имагинарна, имагинарно „конструисана” у позитивном смислу речи. Зато Горану није пресудна прича, фабулација, јер је у његовој прози све сценично, иконографски живо, филмично: његов опус је једна велика, покретна наративно-језичко-ликовна композиција. А слика, каже Дерида, само је оквир онога што се не може уоквирити, константно уоквиравање; слика је увек метаслика... О тој прози, прози Горана Петровића, која се не може уоквирити, која себе изнова и изнова уоквирава, која је филмичнија од филма, сликовитија од слике, а све то посредством аутентичног поетичког преобликовања и књижевнопоетичке и језичке грађе, требало би да се напише макар један докторат.

Уколико Адорно тврди да је претежни део филозофског посла управо језичкокритичког карактера (в. Адорно 1979), што ће чак потврдити и Дерида, указујући на неотклоњиву напетост између концепције целовитости и апорија и парадокса који тај концепт прате, Адорно онда минира самога себе: од Хајдегера задата етимолошка обрада филозофске терминологије не може бити ништа друго до буђење бића закопаног у терминима и у речима, што је егзистенцијалистичко место борбе за језик, коју, у структуралистичком смислу судбине знака, од Јакобсона, преко Барта, до Дериде пратимо. Буђење 
или раскривање трага, рекао би исти Дерида, или знака, рекао би Барт, оног жанра, рекао би Бахтин, оног културно-поетичког обрасца по којем роман постоји, рекао би Џејмсон. А тај образац, адорновски, хоће један склоп/ однос између речи, хоће, бахтиновски, дијалогичност речи и дијалошко испитивање поетике, хоће, деридијански, онај траг којим је знак подељен и условљен... А Горан Петровић хоће све то, јер његова поетика јесте историјски, тачније археолошки, али и будући облик наративне седиментације. Не у смислу авангардног „космичког вихора који дува у речима”, више у смислу ископина у култури, у речима. Не ни у смислу сажетости речи, колико у њиховој бескрајно дубокој, покретној слојевитости. Не у смислу лексикографске парадигме, колико у смислу наративно-археолошке парадигме. Можда у Бахтиновом смислу: „што је жанр развијенији и сложенији то се потпуније сећа своје прошлости”. (Бахтин 2000: 115)

„Већ после неколико тренутака учиниће нам се и сама реч и њен склоп чудни, као први пут измишљени”, каже, као да говори о Горану, Растко; „Сваки израз имао би своју вредност, нарочито обновљену и доказану за ово дело, које би тако било састављено као из неког тек новопронађеног језика који бисмо одмах и разумели чим бисмо га чули” (Петровић 19746: 411) - зар и овде није зачуђујуће да Растко није замишљен над Горановим делом. „Цела поезија подсвести, асоцијација, аутоматизма приближава се и нехотице више народу, нашим бројаницама, ако се тако сме рећи, но што је продужила уметност која је непосредно била за њом" (Петровић 19746: 357) - и овде као да презимењак прича о будућем му презимењаку. Као да је - рецимо то овако - у самим својим почецима, култура била обликована онако како то своју прозу обликује Горан Петровић.

Зато, можемо тврдити, Петровићева нарација води ка оном што је мистификовано историјом, дискурсом, „политиком”, ка оном што заклања хумано лице и што 
се открива у причи, и то тако сажетој причи, једноставној у фабуларном смислу попут приче за децу, али тако развијеној и сложеној у трополошко-језичком смислу. Горан, зато, приповеда језик а не фабулу, а прича се у тој језичкој нарацији проналази и губи. Петровићева поетика поништава све оно дискурзивно које стратификује нашу стварност, и води нас негде, све даље и даље, ван устаљене логике света, у културолошко-антрополошки идентитет „језичког” наратива. Као што, дакле, жртвује историјско-друштвене матрице и причу неком најједноставнијем прозном облику, нпр. бајци, једној наративној схеми која доводи причу до критичне границе где она скоро доживљава сопствено самоукинуће, Петровић жртвује и догађаје језику, једну фабуларну механику поетичко-сликовитој могућности своје наративне синтаксе. Горанова проза се налази управо на тој ивици, на ивици, кажимо овако, где се нарација претвара у пиктурацију, прича у слику, фабула у троп. Јер Петровићева језичкоархеолошка поетика - умрежење речи, његове метафоре и слике, неочекивани лексички спојеви, јасно и деликатно промишљене и парадоксалне синтагме - успоставља заборављене односе између ствари и појава, речи и ствари, речи и слике, и изнова поставља космос у његову никада довршену и изнова довршавајућу целовитост. Зато је, у логоцентричном смислу, немогуће превести Петровићеве тропе: они су средство посредног означавања, удвојених слика, алузија и загонетки, они су место где се прича губи заједно са потенцијалним преводом, и то не на страни него на исти, српски језик. Да, прича Горана Петровића се не може превести на неко дословно значење, на неку, рационално схваћено, уобичајену фабулу. Не може јер потиче из фигурације, јер прича није потка нарације, ни њен производ: прича дакле није на месту где је очекујемо и у облику у којем је очекујемо. Требало би, сматрам, развити једну другачију теоријску хермене- 
утику, херменеутику имагинације и тропизације, херменеутику која би, на Башларовом трагу, разумела причу као сањарију знакова, причу коју прича оно иза тропа, тако далеко од фабуларне матрице. Требало би мислити књижевност у духу једне имагинарне, метапоетске транстеорије, која би коначно раскинула са метефизичким и позитивистичким едипализацијама (превод, дословност, фабула и сл), и која би са Горановом прозом остала заувек не изгубљена него искупљена у имагинарној немогућности свођења на нешто друго, у немогућности „превода”...

Ако сам рекао да Горан жртвује причу слици, сада бих то развио до следеће тезе: стварајући тако комплексну визуелну поетику прозе, Горан је истовремено и поништава. Уможавајући увек динамичне тропе, метафоре и слике на квадрат и куб, Горан нас води до извора непредстављивог, до оне архиседиментиране сликовитости. Парадоксално, дакле, двострука или петострука метафорика, као што укида дословно значење, тако укида и саму себе, саму метафоричност, пластично дочаравање ствари, и отвара пут ка непредстављивом, неспознатљивом, неприкосновеном простору унутар фигура. Када, дакле, речи „оспоравају” једна другу и када се метафоре једна другој „супротстављају”, када се само изнова и изнова уоквиравају, тада настају семантичка поља која нас доводе у стање да имагинирамо оно што се не може имагинирати, да видимо невидљиво. Самоумножавање тропике, њихово појачавање и потискивање, води нас не-виђеном, не-описивом, не-преводивом, не-испричивом, једном стању првобитног, превавилонског језика и нарације, када су реч, слика, ствар и биће били једно и када су причали ону тако велику причу света.

Зато, иако нисам то проверавао и бројао, лично мислим Горана Петровића као писца са највећим бројем речи, можда тачније лексичких тропа, у историји српске књижевности. А, опет, парадоксално, ова бескрајноречивост 
Горановог дискурса ствара осећај изражајног ћутања, карактеристичног за средњовековну, византијску поетику. Као што је на граници слике, на граници имагинације, на граници приче, Горанова нарација је исто тако и на граници немости. Горанова тропика и лексика међусобно се укрштају, условно „поништавају”, не би ли нас пребациле иза, с оне стране себе самих, у културногеолошку, културноархеолошку, културнометафизичку или хуманистичку нарацију тишине. У наративно ћутање бића или у преседиментацијску загонетку над загонеткама и то као крајњу и увек књижевну одгонетку свих загонетки.

Можда би мој закључак требало да гласи да Петровићева нарација не потире себе саму него она понире у себе саму, у себи иманентан књижевнокултуролошки тунел. Није ли то онда залог непоновљиве аутентичности његове прозе. Наративни, археологизовани ларпурлартизам, једна надмоћна игра артифицијелности. Игра над празнином света и заборавом бића која чува и свет и биће света. Игра коју само археолошка нарација и пиктурална прозна поетика могу изнова или по први пут разиграти. У име књижевности, културе и човека. И читалац тако може угледати слику самог бића света, чијом је неурамљеношћу и неуквиреношћу обухваћен истински хуманистички пејзаж постојања. Послушајмо зато Горана:

„Има, оно што још није написано, а што ће једног дана постати део књижевности коју неко други исписује. Ја мислим да књижевност јесте живот, да је приповедање потреба која је старија, чак и од писаног језика. Та потреба је вечита. И ту је снага књижевности. Велика заблуда модерне цивилизације је да је све у информацији, а није зато што у њој нема људских судбина... Обратите пажњу једанпут, гледајте било који канал у било којој земљи 
и видећете како доле трчи кајрон, односно како трче информације где се спомињу десетине, стотине страдалих у земљотресу, у поплави, ту су убиства, ратови... А све су то људи. И сваки од њих има своју причу. Али у кајрону тога нема. А ми остајемо у заблуди да смо нешто сазнали. Ја сматрам да је књижевност супротстављена историографији. Историографија је дисциплина која добија увек нов материјал. Једнога дана ви ћете имати књигу или уџбеник о овом нашем периоду који можда неће бити споменут ни у фусноти, јер ће у међувремену за, не знам колико стотина година, бити много неких важнијих догађаја, а ми мислимо да је наше време веома важно. Књижевност је у том смислу заиста све. Она је опомињућа, она је једна врста бележења људскости." (Петровић 2019а)

Књижевност је, дакле, један начин бележења, означавања, обележевања, жигосања. Она је белег, тетоважа, ожиљак, жиг. Литература је белег којим се, парафразирајмо Дериду, наизглед одсутно биће литературе уписује у нови литерарни текст. Приче, романи су трагови, ожиљци, они су археолошки самоприкривени делови поетичке синтаксе приповедача. А забележити знак увек за Горана Петровића значи забележити на било шта друго несводиву људскост, у једном континуитету бележења, приповедања, приче, као раскривања белега, идентитета, а тако и хуманости. Јер бележење је за Горана чување; јер белег, реч, увек су људски; јер литерарни белези и литерарно архивирање јесте место отпора нестанку и забораву:

„Неком приликом, у разговору, тај ми је Швеђанин рекао да му је недавно умрла мајка. Рекао је то с примереном, очекиваном тугом. А онда је сетно додао, чак са ужасом у гласу, како му се чини да су од тог тренутка, с мајчиним вечним одласком, 'отишле', нестале неке речи... О свему овоме смо причали на трећем, енглеском језику. Изгубити, дакле, реч каткад значи изгубити и осећање...” (Петровић 20196) 
Петровић тако реч види неодвојиву од човека, дубоко урезану у њега, обележену њиме и обрнуто; нема човека без речи, приче, и обрнуто; убити реч једнако је убити човека, и, опет, обрнуто. Читам даље Горана како кишовски изјављује: „Књижевност је једна од ретких преосталих човекових дисциплина која се још увек пита - ко сам, где се налазим, шта то радим..." (Петровић 20196). И осећам колико ми је то блиско, просветитељски, елементарно људски и патетично људски блиско. Док је књижевносии и, за човека, gакле, има увек наgе - чујем Горана како ми, онако стидљиво осмехнуто и скромно, како он то иначе чини, али истовремено и тако епски круто, решено и срчано говори. Можда исто овако стидљиво и људски патетично као што сам и вама и Горану, и ја овом једнодневном, на 37 степени, медитацијом о Горановој поетици говорио. Стидљиво и патетично желећи само да вам кажем: Читам и пишем, и знам и ко сам, и где се налазим, и шта радим...

\section{ЛИТЕРАТУРА}

Адорно 1979: T. Adorno, Estetička teorija, Београд: Нолит.

Бахтин 2000: M. Bahtin, Problemi poetike Dostojevskog, Beograd: Akademska knjiga.

Дерида 2001: Ž. Derida, Nasilje i metafizika: Ogled o misli Emanuela Levinasa, Beograd: Plato.

Петровић 1974а: Р. Петровић, Поезија. Сабиюанке, Београд: Нолит.

Петровић 19746: Р. Петровић, Есеји и чланизи, Београд: Нолит Петровић 2001: G. Petrović, Hvatač paralelnih života (intervju), $<$ http://arhiva.glas-javnosti.rs/arhiva/2001/01/13/srpski/ I01011201.shtm>

\section{Приступљено 14/6/2019}

Петровић 2011: G. Petrović, Život u tri kutije (intervju)

$<\underline{\text { http://www.novosti.rs/vesti/kultura.71.html:322268-Goran-Pet- }}$ 
rovic-Zivot-u-tri-kutije > Приступљено 17/6/2019

Петровић 2019a: G. Petrović, U kajronu koji trči nema ljudskih sudbina (intervju)

$<$ https://rs-lat.sputniknews.com/intervju/201903031119031154

-goran-petrovic-intervju/> Приступљено 25/6/2019

Петровић 20196: Г. Петровић, Каgа би се йојавио нови Рајс, он

би био или каменован, или макар наружен у коменитарима читиалаиза! (интервју)

$<$ https://iskra.co/intervju/intervju-iskre-goran-petrovic-kn-

jizevnik-kada-bi-se-pojavio-novi-rajs-on-bi-bio-ili-

kamenovan-ili-makar-naruzen-u-komentarima-citalaca/>Приступљено 25/6/2019

Dragan B. Boskovic

\section{A LITTLE, ONE-DAY, AT 37 DEGREES CELSIUS, MEDITATION BY DRAGAN BOSKOVIC ON THE POETICS OF GORAN PETROVIC}

\section{Summary}

The text was supposed to address the marks/imprints/traces of humanity in the opus of Goran Petrovic and his autopoetic defense of literature. It, however, discusses the poetics of Goran Petrovic, understood as literary and cultural sedimentation, and, along with Petrović and Foucault, as archaeological poetics. And Goran Petrovic's poetical and archaeological signs have been recognized as transhistorical traces of humanity. For that reason, what can be sensed in the text is the spirit of faith in literature, a fundamentally human faith and hope that, while writers and literature exist, not everything has gone to rack and ruin.

Key words: Goran Petrovic, literature, poetics, archaeological poetics, (literary and cultural) sedimentation, word-image, humanity 